\title{
Fatty Acid Composition of Diploid and Triploid Populations of Tench (Tinca tinca L.)
}

\author{
H. BUCHTOVÁ 1 , M. SMUTNÁ ${ }^{1}$, L. VORLOVÁ ${ }^{1}$, Z. SVOBODOVÁ ${ }^{1,2}$, M. FLAJŠHANS $^{3,4}$ \\ ${ }^{1}$ University of Veterinary and Pharmaceutical Sciences, Brno, Czech Republic, \\ ${ }^{2}$ University of South Bohemia České Budějovice, Research Institute of Fish Culture and \\ Hydrobiology at Vodňany, Czech Republic, \\ ${ }^{3}$ Joint Laboratory of Genetics, Physiology and Reproduction of Fish, Institute of Animal Physiology \\ and Genetics, Academy of Sciences of the Czech Republic and University of South Bohemia \\ České Budějovice, Research Institute of Fish Culture and Hydrobiology at Vodňany, Czech Republic \\ ${ }^{4}$ Department of Fishery, Faculty of Agriculture, University of South Bohemia \\ Ceské Budějovice, Czech Republic
}

Received January 20, 2004

Accepted June 17, 2004

\begin{abstract}
Buchtová, H., M. Smutná, L. Vorlová, Z. Svobodová, M. Flajšhans: Fatty Acid Composition in Diploid and Triploid Populations of Tench (Tinca tinca L.). Acta Vet. Brno 2004, 73: $235-245$.

The aim of the study was to determine the differences in the composition of fatty acids of intramuscular lipids between diploid ( $2 n$ ) and triploid ( $3 n)$ tench of identical genetic specifications and raised under the same conditions, in relation to sex (F-female vs. M-male) and age ( $\mathrm{T}_{3}-36$ months vs. $\mathrm{T}_{3+}-42$ months). A total of 137 tench (Tinca tinca $\mathrm{L}$.) siblings were analyzed. The control group consisted of 72 diploid tench (39 F and $33 \mathrm{M}$ ) and the experimental group of 65 triploid tench ( $38 \mathrm{~F}$ and $27 \mathrm{M}$ ). Elevated levels of fatty acids $\mathrm{C} 16: 0, \mathrm{C} 16: 1 \mathrm{n}-9 \mathrm{c}$ and $\mathrm{C} 18: 1 \mathrm{n}-9 \mathrm{c}$ were found in lipids of tench of both age groups $\left(\mathrm{T}_{3}\right.$ and $\left.\mathrm{T}_{3+}\right)$. Among $\mathrm{T}_{3}$ tench, significant ploidy-level related differences were ascertained in the content of specific SFA (C12:0, C13:0, C14:0, C15:0; $p<0.01)$ and C22:1n-9 $(p<0.05)$ in favour of $2 \mathrm{n}$ males. A significant effect of sex was found only in the diploid tench population: $\mathrm{C} 14: 0, p<0.01$ and $\mathrm{C} 14: 1 \mathrm{n}-9 \mathrm{c}, p<0.05$ in favour of $2 \mathrm{n}$ male tench and C18:1n-9c, $p<0.01$ in favour of $2 \mathrm{n}$ female tench. In the $\mathrm{T}_{3+}$ age group, the ploidy-level effect was apparent in both sexes $(\mathrm{C} 15: 0, \mathrm{P}<0.05$ and $\mathrm{C} 18: 2 \mathrm{n}-9 \mathrm{c}, \mathrm{t} 11, p<0.05$ in favour of $2 \mathrm{n}$ female tench, C16:1n-9c, $p<0.01$ in favour of $3 n$ male tench, C18:2n-6c, $p<0.01$ and C18:3n-3, $p<0.05$ in favour of $2 \mathrm{n}$ male tench). In the $\mathrm{T}_{3+}$ age group, the effect of sex was apparent for both ploidy levels (C16:1n-9c, $p<0.01$ in favour of $2 \mathrm{n}$ female tench, and C14:0, $p<0.05$ in favour of $3 \mathrm{n}$ male tench). The qualitative as well as quantitative composition of lipids of specific fatty acids was significantly affected $(p<0.05, p<0.01, p<0.05)$ by age. The study demonstrated that the factors monitored (ploidy, sex and age) may, under specific experimental conditions, influence the composition of lipid fatty acids of the tench.
\end{abstract}

Fatty acids, diploid and triploid tench, genome polyploidy

The existing inter- and intra-species variability in the composition of fatty acids of fish lipids (and of the specific PUFA in particular) is usually explained by the existence of a large number of external factors (type of aquatic environment, type of rearing and the fish culture composition, trophic aspects - interaction, type and composition of diet, season of the year - water temperature) and internal factors (fish species, feeding regime and digestion, lifecycle stage, quantitative and qualitative characteristics of lipids - triacylglycerols, phospholipids and their topographical origin - dorsal vs. ventral part of muscle tissue).

In recent years, there has been a large number of experimental studies (e.g. Cs en geri et al. 1978; Farkas et al. 1978; Vanderwesthuyzen et al. 1984; Suzuki et al. 1986; Viola et al. 1988; Bieniarz et al. 2000) into some of the above factors (dealt with separately or in combination) causing changes in the composition of fatty acids in various fish species. 
Other authors have studied the impact that various types of heat treatment will have on the fatty acid composition (e.g. Gall et al. 1983; Maeda et al. 1985; Tothmarkus and Sasskiss 1993; Fajmonová et al. 2003).

In the case of tench, issues of food composition and availability have been studied by Pyka (1996), the fish culture composition and trophic interactions influencing the fatty acid composition have been dealt with by, e.g. Broenmark (1994), Vácha and Tvrzická (1995) and Steffen s et al. (1998). The relationship between different fish rearing methods and fish oil composition has been studied by Vácha and Tvrzická (1998) and Quirós and Alvariňo (1998).

The above authors generally agree that the composition of specific PUFA in fish is a result of a number of factors, the principal ones being availability, type and composition of the diet, the feeding regime and the type of digestion of the fish species studied. This fact was pointed out for the first time by Burr and Burr (1930), who had found that some PUFA, although they are considered as essential acids (C18:2n-6, C18:3n-3), were not synthesized by some animals and had to be supplied in food.

Some other factors that may influence the composition of fish oils, e.g. ploidy, sex and age (growth) have not been studied in tench yet.

The aim of the study reported here was to determine the differences in the quantitative and qualitative compositions of fatty acids in intramuscular lipids (FA IML) and the total amounts of saturated $\left(\mathrm{SFA}_{\text {sum }}\right)$, mono-unsaturated $\left(\mathrm{MUFA}_{\text {sum }}\right)$ and poly-unsaturated n-3 (PUFA n- $3_{\text {sum }}$ ) and n-6 (PUFA n- $6_{\text {sum }}$ ) fatty acids and their ratio (n-6 to n-3) between diploid $(2 n)$ and triploid (3n) tench of an identical genetic specification and reared under the same conditions, in relation to sex (female F vs. male $M$ ) and age of the fish $\left(T_{3} v s . T_{3+}\right)$.

The study was a part of a comprehensive evaluation of diploid and triploid tench, and is a continuation of the already published papers by Buchtová and Vorlová (2002) and Buchtová et al. (2003ab).

\section{Materials and Methods}

Artificial spawning was used in 1998 to establish a genetically identical tench population in the Vodňany hatchery of the Department of Fish Genetics and Breeding of the Research Institute of Fish Culture and Hydrobiology at the South Bohemian University České Budějovice. Part of fertilized eggs of this diploid (2n) population was subjected to a cold shock to induce triploidy ( $3 \mathrm{n}$ ) by fusion with the secondary polar body according to Flajšhans and Linhart (2000).

The tench were reared under identical conditions in experimental ponds of the Research Institute at Vodňany. The $2 \mathrm{n}$ tench fry were freeze-branded, and the $3 \mathrm{n}$ fry were left unmarked.

Before both analyses, the fish harvested $\left(\mathrm{T}_{3}: 27\right.$ March $2001, \mathrm{~T}_{3+}: 10$ Oct. 2001) were put into tanks with original pond water under stress-eliminating conditions $\left(\mathrm{O}_{2}\right.$ above $80 \%$ saturation, constant water temperature).

The tench were sexed based on the expressed sexual dimorphism (120 tench), and pathological and anatomical examination of gonads was used in 10 specimens according to K vasnička and Flajšhans (1993). Diploids were identified according to their freeze-branded marks.

Ploidy level in $3 \mathrm{n}$ tench was checked by flow cytometry as relative DNA content in cell nuclei according to Vindelov and Christensen (1990) using blood sampled by puncture from the caudal vein (vena caudalis), and from histological preparations (7 specimens) according to Flajšhan s et al. (1993).

A total of 137 specimens of $2 n$ and $3 n$ tench (Tinca tinca $L$.) of both age groups $\left(T_{3}\right.$ and $T_{3+}$ ) were studied. Altogether 38 mixed samples of fillets with skin removed (muscle tissue) of tench divided by ploidy, sex and age were analyzed.

For the determination of fatty acids, gas chromatograph Pye Unicam PU 4550 (Philips, UK) was used with the following settings: temperature programme PTGC $\left(60^{\circ} \mathrm{C} 2 \mathrm{~min}\right.$., $10^{\circ} \mathrm{C} / \mathrm{min}$. up to $180^{\circ} \mathrm{C} 1 \mathrm{~min} ., 5^{\circ} \mathrm{C} / \mathrm{min}$. up to $220{ }^{\circ} \mathrm{C} 5 \mathrm{~min}$.), detector FID $200{ }^{\circ} \mathrm{C}, \mathrm{H}_{2}$ flow rate $30 \mathrm{ml} / \mathrm{min}$., air $350 \mathrm{ml} / \mathrm{min}$., injector temperature $200{ }^{\circ} \mathrm{C}$, dose $1 \mu$.

The indices studied included the quantitative and qualitative compositions of fatty acids in intramuscular lipids (FA IML) and the total amounts of saturated ( $\left.\mathrm{SFA}_{\text {sum }}\right)$, monounsaturated (MUFA sum $_{\text {s. }}$ ) and polyunsaturated $\mathrm{n}-3$ (PUFA n- $3_{\text {sum }}$ ) and n-6 (PUFA n- $6_{\text {sum }}$ ) fatty acids and their ratios (n-6 to n-3) among diploid (2n) and triploid (3n) tench of identical genetic specifications and reared under the same conditions, in relation to sex (female F vs. male $\mathrm{M})$ and age of the fish $\left(\mathrm{T}_{3}\right.$ vs. $\left.\mathrm{T}_{3+}\right)$. 
Basic statistics (mean, S.D.) were calculated in EXCEL 97. Multifactorial variance analysis was used for the evaluation of statistical significance of results on a static level (separately for $\mathrm{T}_{3}$ and $\mathrm{T}_{3+}$ ) according to tench ploidy and sex (ANOVA, Statgraphics 5.0). Using single factorial variance analysis (ANOVA, Excel 97), the statistical significance of increasing fish age on the parameters studied on the dynamic level $\left(T_{3}-T_{3+}\right)$ performed separately for individual tench groups (F 2n, M 2n, F 3n, M 3n) was * $p<0.05$, ** $p<0.01$ and $* * * p<0.001$.

\section{Results}

Lipids of tench in both age groups $\left(\mathrm{T}_{3}\right.$ and $\mathrm{T}_{3+}$ ) contained mainly palmitic (C16:0), palmitoleic $(\mathrm{C} 16: 1 \mathrm{n}-9 \mathrm{c})$ and oleic $(\mathrm{C} 18: 1 \mathrm{n}-9 \mathrm{c})$ acids. Also represented were n-6 (linoleic acid, C18:2n-6c) and n-3 ( $\alpha$-linolenic acid, C18:3n-3) essential fatty acids. Fatty acids with a higher number of carbon atoms and double bonds in molecules characteristic for fish lipids were not present in detectable amounts in $\mathrm{T}_{3}$ tench under the experimental conditions. In lipids of $\mathrm{T}_{3+}$ tench, arachidonic acid $(\mathrm{C} 20: 4 \mathrm{n}-6 \mathrm{c})$ and eicosapentaenoic acid (C20:5n-3) were also found. No docosahexaenoic acid (C 22:6n-3) was found in lipids of $\mathrm{T}_{3+}$ tench (Tabs 1 and 2).

The qualitative and quantitative composition of FA IML (mean, S.D.) of $\mathrm{T}_{3}$ tench in relation to ploidy (F 2n vs. F 3n, M 2n vs. M 3n) and sex (F 2n vs. M 2n, F 3n vs. M 3n) is given in Table 1. It also gives the overall statistical significance of ploidy and sex on individual parameters for each of the tench groups (F 2n, M 2n, F 3n, M 3n).

In $\mathrm{T}_{3}$ tench, ploidy level affected the FA IML composition in males only. Highly significant $(p<0.01)$ differences in the levels of individual SFA (C12:0, C13:0, C14:0, C15:0) in favour of $2 \mathrm{n}$ males were found. In this tench group (M 2n), erucic acid levels (C22:1n-9) were significantly higher $(p<0.05$, Tab. 1$)$.

A significant effect of sex was found in the $2 \mathrm{n}$ tench population only. In $2 \mathrm{n}$ males, a highly significant $(p<0.01)$ increase in the level of myristic acid (C14:0) and a significantly $(p<$ $0.05)$ higher level of myristicoleic acid (C14:1n-9c) were found. The highly significant $(p<$ $0.01)$ increase in oleic acid levels $(\mathrm{C} 18: 1 \mathrm{n}-9 \mathrm{c})$ in lipids of $2 \mathrm{n}$ females was probably the reason for significantly $(p<0.05)$ higher level of MUFA sum $_{\text {in }}$ in female group.

The qualitative and quantitative composition of FA IML (mean, S.D.) of $T_{3}$ tench in relation to ploidy level (F 2n vs. F 3n, M 2n vs. M 3n) and sex (F 2n vs. M 2n, F 3n vs. M 3n) is given in Tab. 2. It also gives the overall statistical significance of ploidy levels and sex on individual parameters for each of the tench groups (F 2n, M 2n, F 3n, M 3n).

In $\mathrm{T}_{3+}$ tench, ploidy level affected FA IML composition in both sexes. Significantly higher $(p<0.05)$ levels of pentadecanoic $(\mathrm{C} 15: 0)$ and octadecadienoic $(\mathrm{C} 18: 2 \mathrm{n}-9 \mathrm{c}, 11 \mathrm{t})$ acids were found in $2 \mathrm{n}$ females. The highly significant $(p<0.01)$ increase in palmitoleic acid levels $(\mathrm{C} 16: 1 \mathrm{n}-9 \mathrm{c})$ in lipids of $3 \mathrm{n}$ males was probably the reason for a significantly $(p<0.05)$ higher level of MUFA sum $_{\text {in the }}$ M 3 n tench group. Significant differences in the level of linoleic acid (C18:2n-6c, $p<0.01)$, linolenic acid $(C 18: 3 n-3, p<0.05)$ and PUFA n-3 sum $(p<0.05)$ in favour of M $2 \mathrm{n}$ values were also found.

In $\mathrm{T}_{3+}$ tench, sex effect on FA IML composition was apparent in both diploid and triploid tench. In $2 \mathrm{n}$ females, a highly significant $(p<0.01)$ increase in the level of palmitoleic acid (C16:1n-9c) was found, which was probably also the reason for a significantly $(p<0.05)$

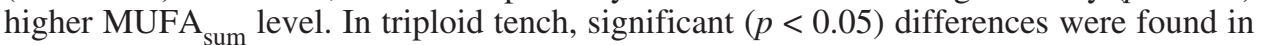
only one SFA (C14:0) in favour of values in 3n males.

A comparison of values of the indices monitored in $\%$ differences due to higher age of tench is given in Figs 1-3. The calculation of differences (in \%) between parameter values monitored obtained by statistical analyses in $\mathrm{T}_{3}$ and $\mathrm{T}_{3+}$ tench is based on the assumption that $\mathrm{T}_{3}$ values were $100 \%$. Significant differences in both the content and the composition of FA IML (Figs $1,2$ and 3$)$ in relation to higher age in tench $\left(\mathrm{T}_{3}-\mathrm{T}_{3+}\right)$ were found. In all tench groups monitored, a highly significant $(p<0.001)$ increase of about 24 to $34 \%$ in the content of SFA sum was found (Fig. 3). The reason for the increase was a highly significant $(p<0.001)$ increase of about 16 to 


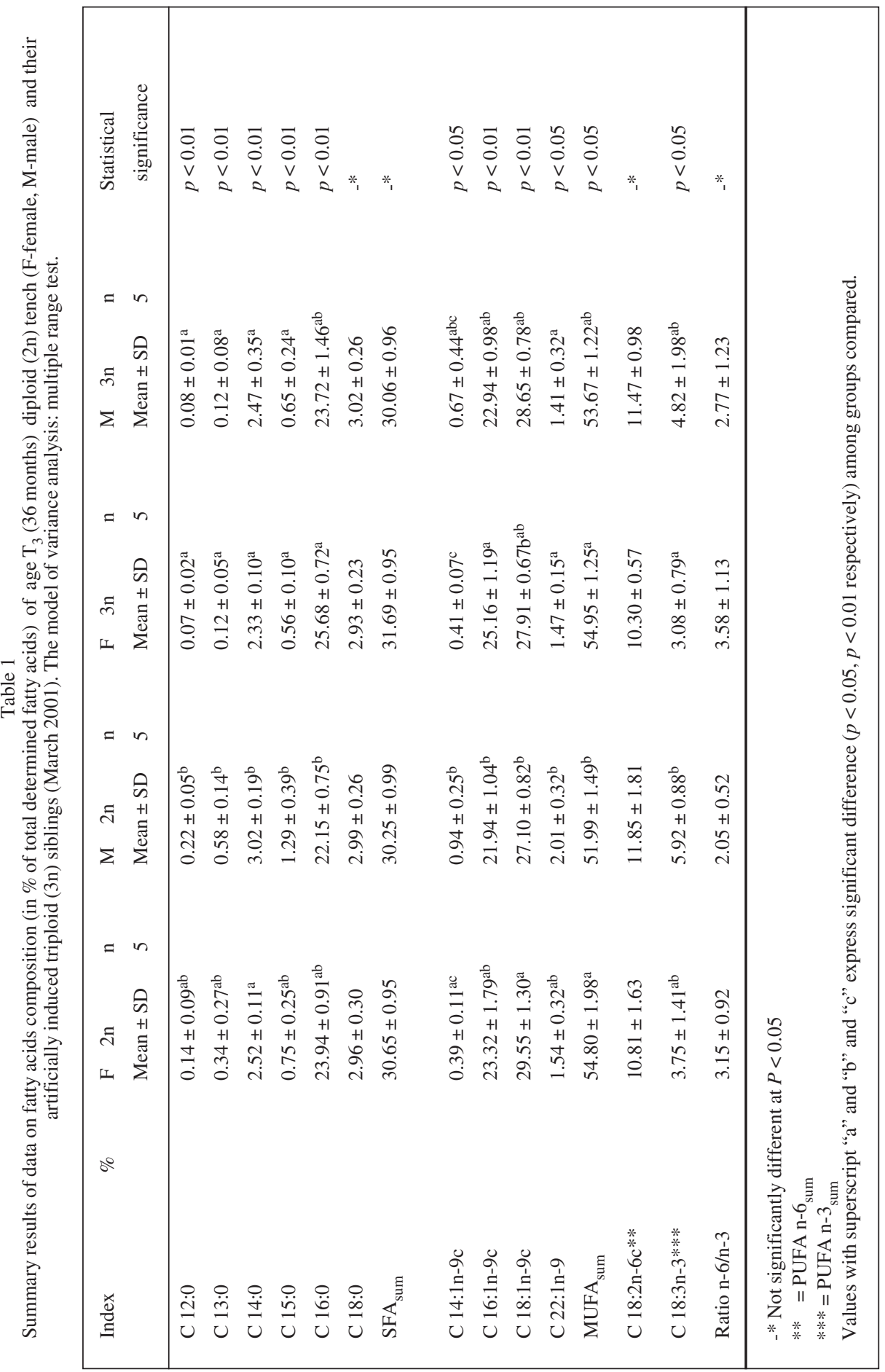


$23 \%$ in the content of the majority palmitic acid (C16:0) (Fig. 1) and of the minority heptadecanoic (C17:0) and arachidic (C20:0) acids, which were not contained in lipids of $\mathrm{T}_{3}$

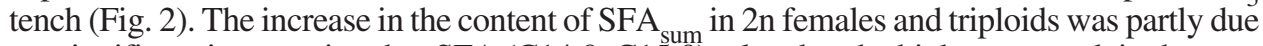
to asignificant increase in other SFA $(\mathrm{C} 14: 0, \mathrm{C} 15: 0)$ related to the higher age, and, in the case of $2 \mathrm{n}$ males, to the absence of minority C12:0 and C13:0 acids in lipids of $\mathrm{T}_{3+}$ tench (Figs 1 and 2). The content of stearic acid (C18:0) remained practically unaffected by age (Fig. 1).

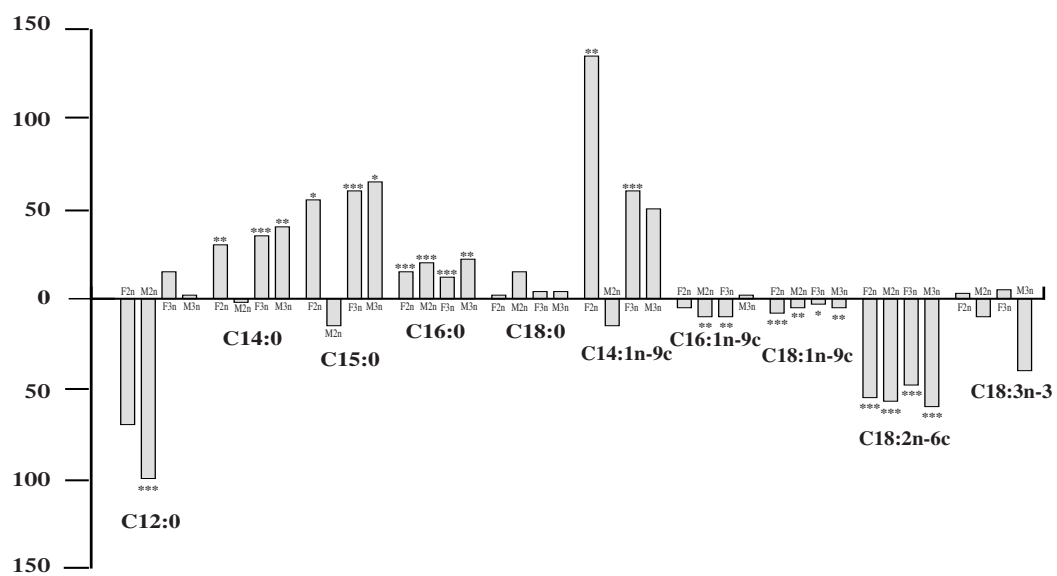

Fig. 1 Comparison of the changes in $\%$ of the contents of fatty acids composition of diploid ( $2 n$ ) and triploid ( $3 n)$ tench (F-female, M-male) during the time from $\mathrm{T}_{3}\left(36\right.$ months) to $\mathrm{T}_{3+}(42$ months $)$ of age. Asterisk *, **,*** express significant difference $(p<0.05, p<0.01, p<0.001)$ among groups compared. The model of variance analysis: one-way.

The significant decrease in the content of MUFA $_{\text {sum }}$ by about 5 to $8 \%$ (Fig. 3) is mainly due to changes in levels of majority acids, i.e. of palmitoleic acid (C16:1n-9c, decrease of about 1 to 10 $\%$ ) and oleic acid (C18:1n-9c, decrease of about 4 to $14 \%$ ) (Fig. 1), and the absence of erucic acid (C22:1n-9) in $\mathrm{T}_{3+}$ tench lipids (Fig. 2). The significant increase in the minority MUFA (C14:1n9c, C15:1, C17:1) had no appreciable effect on the final MUFA ${ }_{\text {sum }}$ content (Figs 1 and 2).

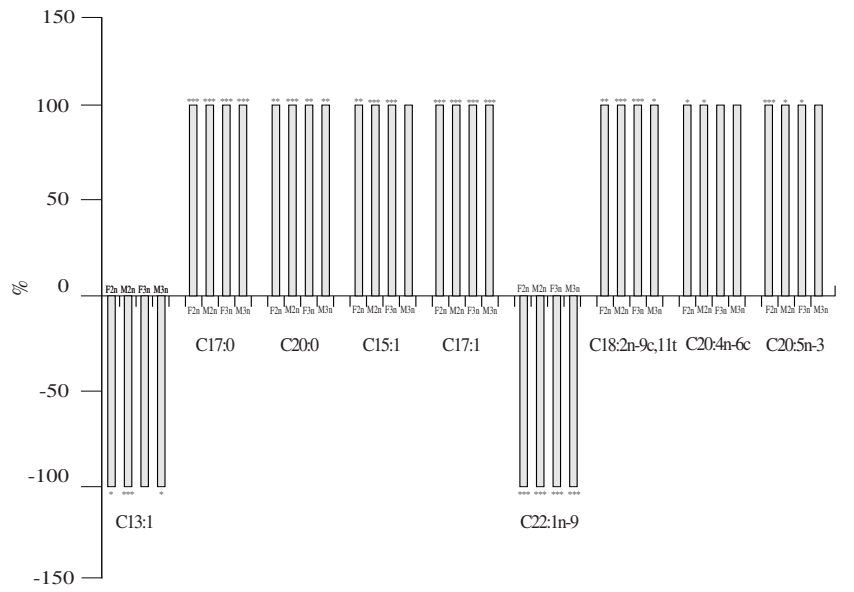

Fig. 2 Comparison of the changes in $\%$ of the contents of fatty acids composition of diploid (2n) and triploid ( $3 n$ ) tench (F-female, M-male) during the time from $\mathrm{T}_{3}\left(36\right.$ months) to $\mathrm{T}_{3+}(42$ months $)$ of age. Asterisk *, $* *, * * *$ express significant difference $(p<0.05, p<0.01, p<0.001)$ among groups compared. The model of variance analysis: one-way. 


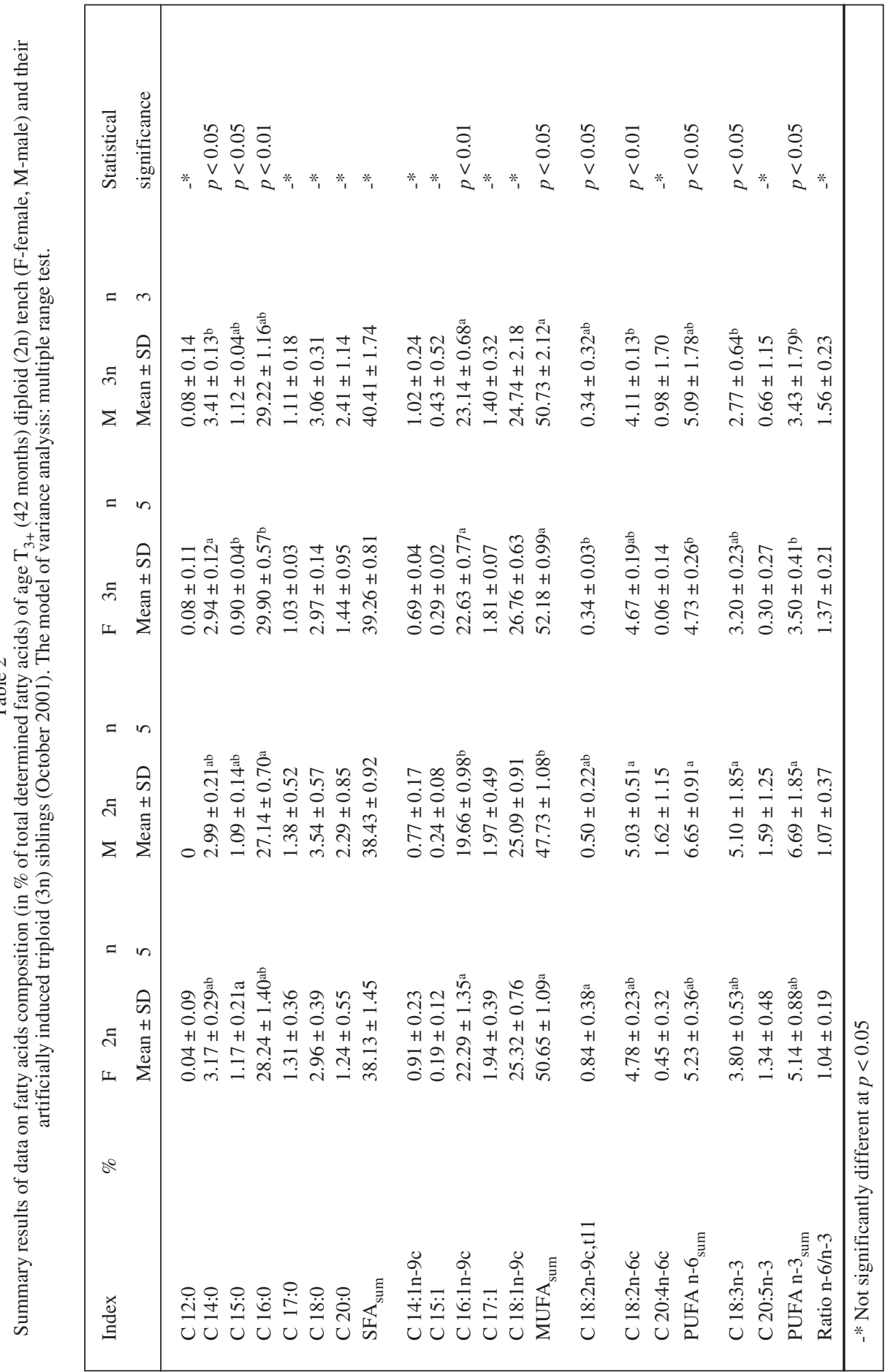


The highly significant $(p<0.001)$ decrease in the content of linoleic acid $(\mathrm{C} 18: 2 \mathrm{n}-6 \mathrm{c})$ of about 55 to $64 \%$ in lipids of $\mathrm{T}_{3+}$ tench (Fig. 1) was the reason for the decrease in the PUFA n- $6_{\text {sum }}$ level of about 44 to $56 \%(p<0.001)$ (Fig. 3$)$. A significant increase $(p<0.05)$ in the content of minority arachidonic acid $(C 20: 4 n-6 c)$ was found in the $T_{3+}$ diploid tench population (Fig. 2).

Age was found to have no significant efect on the content of PUFA n- $3_{\text {sum }}$ in lipids of the tench groups monitored. The non-significant increases in the PUFA n- $3_{\text {sum }}$ level in diploid females (of about $37 \%$ ), diploid males and triploid females (of about 13\%) (Fig. 3) were probably due to the significant levels of eicosapentaenoic acid (C20:5n-3) (Fig. 2) in these $\mathrm{T}_{3+}$ tench groups. The non-significant decrease in the content of PUFA n-3 sum of about 29 $\%$ in $3 n$ males was probably partly due to a non-significant decrease in the content of $\alpha$ linolenic acid (C18:3n-3) (Fig. 1).

The above values and their age-related changes in the content and representation of individual PUFA among tench groups monitored were the reason for the highly significant $(p<0.01)$ decrease in the $n-6$ to $n-3$ PUFA ratio in diploid populations of both sexes, and in $3 \mathrm{n}$ females of about 48 to $67 \%$ (Fig. 3). In 3 n males, the n- 6 to $n-3$ ratio remained practically the same irrespective of age.

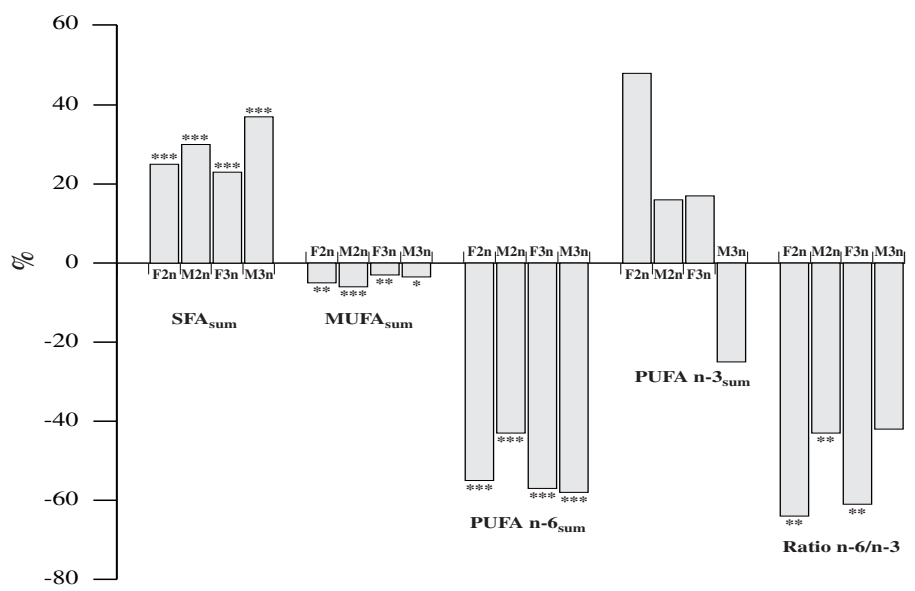

Fig. 3. Comparison of the changes in $\%$ of the contents of $\mathrm{SFA}_{\text {sum }}$, MUFA $_{\text {sum }}$, PUFA n- $6_{\text {sum }}$, PUFA n- $3_{\text {sum }}$ and ratio $n-6 / n-3$ of diploid ( $2 n$ ) and triploid ( $3 n)$ tench (F-female, M-male) during the time from $\mathrm{T}_{3}$ (36 months) to $\mathrm{T}_{3+}$ (42 months) of age. Asterisk $*, * *, * * *$ express significant difference $(p<0.05, p<0.01, p<0.001)$ among groups compared. The model of variance analysis: one-way.

\section{Discussion}

The results of this study indicate that a degree of variability in the composition of fish lipids may in some specific cases be caused, besides generally recognized factors mentioned in connection with changes in their composition, by factors like ploidy level and sex (Tabs 1 and 2) and particularly age (growth) of the fish studied (Figs 1, 2 and 3).

Under the conditions of the experiment reported here, i.e. under identical rearing conditions and using a genetically identical tench population, the factors mentioned were only secondary causes of the statistically significant differences found in the qualitative and quantitative composition of lipids. The primary factors included availability, type and quantity of food received by individual groups of tench (e.g. Burr and Burr 1930; 
Csengeri et al. 1978; Farkas et al. 1978; Vanderwesthuyzen et al. 1984; Suzuki et al. 1986; Viola et al. 1988; Bieniarz et al. 2000), and the related complex biochemical, enzymatic and metabolic processes in the fish organism (Somers et al. 1989, Hoch ach ka and Mommsen 1995).

Accelerated growth of triploid tench populations and a marked sexual dimorphism (Buchtová et al. 2003ab) demonstrated by higher final weight of both $2 \mathrm{n}$ and $3 \mathrm{n}$ tench females result in a qualitative and quantitative selection of the food available. The trophic competition of larger fish limits the choice of food for the more slowly growing tench groups (diploid tench from the ploidy level point of view and male tench and the sex point of view). The predominant type of food (plants vs. animals, natural vs. artificial) that serves as the supply of fatty acids of a specific composition is decisive for the subsequent enzymatic synthesis of SFA, MUFA and PUFA from acetyl-CoA in the fish. The relationship between tench nutrition and the fatty acid composition of their oils (and of specific PUFA in particular) has been studied by a number of authors (e.g. Vácha and Tvrzická 1995, Pyka 1996, Steffens et al. 1998, Vácha and Tvrzická 1998, Quirós and Alvariňo 1998), who pointed out the immediate effect of the type and quality of the food the fish receive.

Different levels of saturation of the organism with some other nutrients affect the feedback and other metabolic processes, and thus also the activity of corresponding enzymes (elongase,

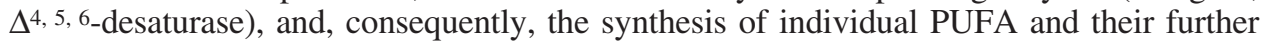
metabolic transformations. The activity of those enzymes is negatively affected mainly by the deficit of vitamins $\mathrm{B}_{6}$ and $\mathrm{H}$ (biotin) and minerals like $\mathrm{Zn}, \mathrm{Mg}$ and $\mathrm{Ca}$. Continental fresh water contains less minerals ( $\mathrm{Zn}$ and $\mathrm{Mg}$ in particular) than sea water, which may theoretically be the reason for the lower levels of specific PUFA in freshwater fish oils. Velíšek (1999) hypothesized that specific elongases and desaturases are also negatively affected by higher intakes of trans-unsaturated fatty acids and structural isomers of natural unsaturated fatty acids in food, and by some other factors like, e.g., age, stress and viral infections.

An analysis of intramuscular lipids of both $\mathrm{T}_{3}$ and $\mathrm{T}_{3+}$ tench showed the predominance of palmitic (C16:0), palmitoleic (C16:1n-9c) and oleic (C18:1n-9c) acids (Tab. 1 and 2), which is characteristic for lipids of animal origin. The same conclusions were made in tench studies by, e.g., Vácha and Tvrzická (1995, 1998), Steffens et al. (1998) and Quirós and Alvariňo (1998).

The spectrum of fatty acids in lipids also contained minor quantities of acids with an odd number of atoms in carbon chains (C13:0 and C15:0 in $\mathrm{T}_{3}$ tench, C15:0, C15:1, C17:0 and $\mathrm{C} 17: 1 \mathrm{~T}_{3+}$ tench), which are relatively rare in natural surroundings (Velíšek 1999).

The highly significant $(p<0.01)$ increase in the content of individual SFA (C12:0, C13:0, $\mathrm{C} 14: 0, \mathrm{C15:0})$ in lipids of $2 \mathrm{n} \mathrm{T}_{3}$ male tench (ploidy effect) is probably related to the highly significant $(p<0.001)$ difference in weight between male tench of both ploidy levels in that age category (M 2n 76.46 $\pm 21.26 \mathrm{~g} ;$ M 3n $191.66 \pm 60.59 \mathrm{~g})$ ascertained in identical tench groups by Bu ch tová et al. (2003ab). The weight differences between males were probably decisive in the selection of food. The depletion of energy reserves during the overwintering period among $2 \mathrm{n} \mathrm{T}_{3}$ males, which was also corroborated by very low fat levels $\left(8.2 \pm 0.4 \mathrm{~g} \cdot \mathrm{kg}^{-1}\right)$ in their muscle tissue (results of a study into the basic chemical composition of muscle tissue in identical tench groups have not been published yet), and probably also the low specific elongases and desaturases activity in tench of this age group were the reasons for the dominant synthesis of SFA from acetyl CoA. In $\mathrm{T}_{3+}$ males, where no significant differences in the final weight were found (M 2n $295.86 \pm 50.05 \mathrm{~g}, \mathrm{M} \mathrm{3n} 444.00 \pm 160.00 \mathrm{~g}$ ), the quantitative representation of SFA present was practically the same. High levels of the myristic acid (C14:0) and myristicoleic acid (C14:1n9c) in lipids of diploid $\mathrm{T}_{3}$ males were the reason for the significant differences between those acids also in relation to sex. 
In lipids of $2 \mathrm{n} \mathrm{T}_{3}$ males, a significantly $(p<0.05)$ higher content of the erucic acid $(\mathrm{C} 22: 1 \mathrm{n}-9)$ was found, which may be due to a trophic competition between heavier $2 \mathrm{n}$ females and $3 \mathrm{n}$ siblings (priority selection of planktonic and benthic organisms), and a higher representation of phytoplankton (or plant food) in the diet of the lowest-weight fish group. Besides the endogenous source of the acid, two-year old diploid male tench may have used another source of the acid, namely the seeds of brassicaceous (Brassicaceae) and tropaeolum (Tropaeolaceae) plants growing around the experimental ponds. The seeds containing the erucic acid in significant quantities contaminated the water in the ponds and may have served as food for the tench.

While no tridecanoic acid C13:0 or erucic acid C22:1n9 were found in lipids of the older $\left(\mathrm{T}_{3+}\right)$ tench group, some other SFA (C17:0, C20:0), MUFA (C15:1, C17:1) and PUFA (C18:2n9c, 11t, C20:4n6c, C20:5n3) were detected. The detection of those polyunsaturated fatty acids in $\mathrm{T}_{3+}$ tench points to enzymatic desaturation and carbon chains elongation in the higher-age categories of fish as a result of favourable living conditions during the summer feeding season. There were practically no differences in the content of individual SFA in the $\mathrm{T}_{3+}$ groups of tench monitored. The only significant $(p<0.05)$ differences were found in females (C15:0) in relation to ploidy level, and in triploids (C14:0) in relation to sex.

Low levels of the palmitic acid (C16:0) in diploid tench males in both age categories $\left(\mathrm{T}_{3}\right.$ and $\left.\mathrm{T}_{3+}\right)$ were probably the reason for the highly significant $(p<0.01)$ differences in the contents of palmitoleic acid and significant $(p<0.05)$ differences in MUFA sum $_{\text {levels, in }}$ relation to ploidy level and sex in $\mathrm{T}_{3+}$ tench.

Ploidy level affected also the PUFA n- $6_{\text {sum }}$ group, where significant $(p<0.05)$ differences in the levels of octadecadienoic acid $(\mathrm{C} 18: 2 \mathrm{n}-9 \mathrm{c}, \mathrm{t} 11)$ in females and highly significant $(p<$ $0.01)$ differences in the levels of linoleic acid (C18:2n-6c) in males were found.

The presence of the docosahexaenoic acid (C22:6n-3), which is characteristic for fish lipids, was not detected in intramuscular lipids of tench of neither are category. According to Vácha and Tvrzická (1998), an abundance of natural food (zooplankton, benthos) has a positive effect on the content of PUFA n-3 in lipids, because, according to Steffens et al. (1998) these fatty acids are contained in natural food in sufficient quantities, while, e.g., wheat contains no PUFA n-3 at all. In the experiment, tench were fed with cereals ad libitum, which may have been the reason for a low intake of natural food. Because no laboratory analysis was made of the extra feed provided, its precise chemical composition is not known and we can only assume that the provision of extra feed in combination with an insufficient endogenous synthesis of specific PUFA from essential $\alpha$-linolenic acid (C18:3n-3) was the probable reason for levels of the eicosapentaenoic acid (C20:5n-3) found and the level (below the perceptibility limit) of the docosahexaenoic acid (C22:6n-3) in intramuscular lipids of the tench groups of both age categories studied. According to the literary references quoted, the presence of specific PUFA is particularly characteristic for fish lipids. The literary references give no hints as to what might be the causes for the low levels of the presence of these specific PUFA in lipids of tench from the two age groups.

The effect of the highly significant $(p<0.001)$ decrease in the level of the essential linoleic acid (C18:2n-6c) with the increasing age of tench appeared in the highly significant $(p<$ 0.001 ) decrease in PUFA $n-6_{\text {sum }}$ of about $44-56 \%$ in lipids of $\mathrm{T}_{3+}$ tench. That in turn affected the decrease ascertained in the n- 6 to $n-3$ ratios to levels shown in Fig. 3. From the quality point of view, intramuscular fat of $\mathrm{T}_{3}$ tench currently reported in the 5-2: 1 range is closer to the optimum n-6 to $n-3$ ratio.

The study demonstrated that the quantitative and qualitative composition of fatty acids in tench may in specific cases be affected by a number of endogenous factors like ploidy level, sex and age. The reason is the proven (Buchtová et al. 2003ab) different rates of somatic growth of tench depending on ploidy level, sex (dimorphism) and age, which primarily 
selectively influences the qualitative and quantitative selection of food, and produces metabolic processes of different intensity and possibly also quality in the organism, which, in specific cases, may lead to the reported significant differences in the composition of intramuscular lipids of tench.

\section{Analýza složení mastných kyselin diploidní a triploidní populace lína obecného (Tinca tinca L.)}

Cílem práce bylo stanovení rozdílů složení mastných kyselin intramuskulárních lipidů mezi diploidními (2n) a triploidními (3n) líny identické genetické specifikace a chovných podmínek v závislosti na pohlaví (F-female vs. M-male) a věku ryb ( $\mathrm{T}_{3}-36$ months vs. $\mathrm{T}_{3+}{ }^{-}$ 42 months). Celkem bylo analyzováno 137 sourozenců lína obecného (Tinca tinca L.). Kontrolní skupinu tvořilo 72 línů 2n (39 F a 33 M) a experimentální skupinu 65 línů 3n (38 F a $27 \mathrm{M})$. V lipidech línů obou věkových kategorií $\left(\mathrm{T}_{3}\right.$ a $\left.\mathrm{T}_{3+}\right)$ byl zjištěn nejvyšší obsah mastných kyselin C16:0, C16:1n-9c a C18:1n-9c. U věkové kategorie línů $\mathrm{T}_{3}$ byly zjištěny signifikantní rozdíly (vliv ploidie) v obsahu konkrétních SFA (C12:0, C13:0, C14:0, C15:0; $p<0.01)$ a v obsahu C22:1n-9 $(p<0.05)$ ve prospěch hodnot 2 n mlíčákủ. Signifikantní vliv pohlaví byl zjištěn pouze u 2 n populace línů: C14:0, $p<0.01$ a C14:1n-9c, $p<0.05$ ve prospěch 2 m mlíčáků a C18:1n-9c, $p<0.01$ ve prospěch 2 j jikernaček. U věkové kategorie línů $\mathrm{T}_{3+}$ se vliv ploidie projevil u obou pohlaví (C15:0, $p<0.05$ a C18:2n-9c, t11, $p<0.05$ ve prospěch 2n jikernaček, C16:1n-9c, $p<0.01$ ve prospěch 3n mlíčáků, C18:2n-6c, $p<0.01$ a C18:3n-3, $p<0.05$ ve prospěch 2 n mlíčáků). Vliv pohlaví se u línů $\mathrm{T}_{3+}$ projevil u obou ploidií (C16:1n-9c, $p<0.01$ ve prospěch 2 n samic, C14:0, $p<0.05$ ve prospěch 3 n samců). Kvalitativní a kvantitativní složení lipidů bylo u konkrétních mastných kyselin signifikantně $(p<0.05, p<0.01)$ ovlivněno věkem. Práce prokázala, že za daných experimentálních podmínek může být v konkrétních případech složení mastných kyselin lipidů lína obecného ovlivněno i těmito sledovanými faktory (ploidie, pohlaví, věk).

\section{Acknowledgements}

This experimental study was supported by the Ministry of Education, Youth and Sports of the Czech Republic (Research Plans No. MSM 162700005, MSM 126100001 and Czech-Chinese bilateral cooperation project KONTAKT No. ME638) and carried out in cooperation with University of South Bohemia České Budějovice, Research Institute of Fish Culture and Hydrobiology (USB RIFCH) at Vodňany. Authors' thanks are due to all collaborators from USB RIFCH and students of the University of South Bohemia České Budějovice for their help during spring and autumn processing the fish and for technical assistance.

The authors are also grateful to Ing. Vítová and other workers from the Institute of Chemistry of Food and Biotechnologies of the Faculty of Chemistry of University of Technology in Brno the qualitative and quantitative determination of fatty acids using the gas chromatograph Pye Unicam PU 4550 (Philips, UK).

\section{References}

BIENIARZ, K, KOLDRAS, M, KAMINSKI, J, MEJZA, T 2000: Fatty acids and cholesterol in some freshwater fish species in Poland. Folia Univ Agric Stetin 27: 2-44

BROENMARK, C 1994: Effects of tench and perch on interactions in a freshwater, benthic food chain. Ecology 75: $1818-1828$

BUCHTOVÁ, H, SVOBODOVÁ, Z, FLAJŠHANS, M, VORLOVÁ, L 2003a: Analysis of slaughtering value of diploid and triploid tench (Tinca tinca, Linnaeus 1758). Czech J Anim Sci 48 Suppl 7: 285-294

BUCHTOVÁ, H, SVOBODOVÁ, Z, FLAJŠHANS, M, VORLOVÁ, L 2003b: Analysis of growth, weight and relevant indices of diploid and triploid population of tench (Tinca tinca, Linnaeus 1758). Aquaculture Research 34: 719-726

BUCHTOVÁ, H, VORLOVÁ, L 2002: Culture, selective breeding and genome manipulations of tench in The Czech Republic. A Review. Folia Veterinaria 46 Suppl 3: 109-112

BURR, GO, BURR, MM 1930: On the nature and role of the fatty acids essential in nutrition. J Biol Chem 86: 587-621

CSENGERI, I, FARKAS, T, MAJOROS, F, OLÁH, J, SZALAY, M 1978: Effect of feeds on the fatty acid composition of carp (Cyprinus carpio L.). Aquacult Hung 1: 24-34 
FAJMONOVÁ, E, ZELENKA, J, KOMPRDA, T, KLADROBA, D, ŠARMANOVÁ, I 2003: Effect of sex, growth intensity and heat treatment on fatty acid composition of common carp (Cyprinus carpio) fillets. Czech J Anim Sci 48 Suppl 2: 85-92

FARKAS, T, CSENGERI, I, MAJOROS, F, OLÁH, J 1978: Metabolism of fatty acids in fish. II. Biosynthesis of fatty acids in relation to diet in the carp, Cyprinus carpio Linnaeus, 1758. Aquaculture 14: 57-65

FLAJŚHANS, M, KVASNIČKA, P, RÁB, P 1993: Genetic studies in tench (Tinca tinca L.). A high incidence of spontaneous triploidy. Aquaculture 110: 243-248

FLAJŠHANS, M, LINHART, O 2000: The production of triploid tench (in Czech). Jihočeská univerzita v Českých Budějovicích VÚRH ve Vodňanech Edice Metodik 2-14

GALL, KL, OTWELL, WS, KOBURGER, JA, APPLEDORF, H 1983: Effects of four cooking methods on the proximate, mineral and fatty acid composition of fish fillets. J Food Sci 48: 1068-1074

HOCHACHKA, PW, MOMMSEN, TP, 1995: Metabolic Biochemistry (Biochemistry and molecular biology of fishes). 1 Ed Elsevier Amsterdam, 515 p.

KVASNIČKA, P, FLAJŠHANS, M 1993: A method of morphological identification of triploids in young brood stock of tench (in Czech). VÚRH Vodňany Edice Metodik 42: 5-8

MAEDA, Y, ISHIKAWA, M, YAMAMOTO, M, TERADA, S, MASUI, T, WATANABE, Y 1985: Effect of cooking on contents of fatty acids, especially eicosapentaenoic acid and docosahexaenoic acid in sardine. J Jpn Soc Nutr Food Sci 38: 447-450

PYKA, J 1996: Feeding of the tench, Tinca tinca (L.), larvae and fry under pond rearing conditions. Arch Pol Fish 4 Suppl 1: 69-84

QUIRÓS, M, ALVARIŇO, JMR 1998: Major fatty acid composition and lipid content in tench (Tinca tinca). A comparison between two different culture systems. Pol Arch Hydrobiol 45 Suppl 3: 347-351

SOMERS, SD, CHAPKIN, RS, ERICKSON, KL 1989: Alteration of in vitro murine peritoneal macrophage function by dietary enrichment with eicosapentaenoic and docosahexaenoic acids in menhaden fish oil. Cell Immunol 123 Suppl 1: 201-211

STEFFENS, W, WIRTH, M, FÜLLNER, G 1998: Fatty acid composition of tench (Tinca tinca L.) under different nutritional conditions. Pol Arch Hydrobiol 45 Suppl 3: 353-359

SUZUKI, H, OKAZAKI, K, HAYAKAWA, S, WADA, S, TAMURA, S 1986: Influence of commercial dietary fatty acids on polyunsaturated fatty acids of cultured freshwater fish and comparison with those of wild fish of the same species. J Agric Food Chem 34: 58-60

TOTHMARKUS, M, SASSKISS, A 1993: Effect of cooking on the fatty acid composition of silver carp (Hypophtalmichtis molitrix V.). Acta Alimentaria 22: 25-35

VÁCHA, F, TVRZICKÁ, E 1995: Content of polyunsaturated fatty acids and cholesterol in muscle tissue of tench (Tinca tinca), common carp (Cyprinus carpio) and hybrid of bighead carp (Aristichthys nobilis) with silver carp (Hypophthalmichthys molitrix). Pol Arch Hydrobiol 42 Suppl 1-2: 151-157

VÁCHA, F, TVRZICKÁ, E 1998: Polyunsaturated fatty acid proportion in fat of tench (Tinca tinca) under different rearing conditions. Pol Arch Hydrobiol 45 Suppl 3: 337-346

VELÍŠEK, J 1999: Chemie potravin (in Czech). OSSIS Tábor pp. 3-72

VINDELOV, LL, CHRISTENSEN, IJ 1990: Review of techniques and results obtained in one laboratory by an integrated system of methods designed for routine clinical flowcytometric DNA analysis. Cytometry 11: 753-770

VIOLA, S, MOKADY, S, BEHAR, D, COGAN, U 1988: Effects of polyunsaturated fatty acids in feeds of tilapia and carp. 1. Body composition and fatty acid profiles at different environmental temperatures. Aquaculture 75: 127-137

VANDERWESTHUYZEN, J, CHETTY, N, GIBSON, JE, BRADLOW, BA 1984: Fatty acid composition of a fish diet. S Afr J Sci 80: 330-331 